TILTAI, 2016, 3, 49-59 ISSN 1392-3137 (Print), ISSN 2351-6569 (Online)

\title{
KOKYBIŠKA IR TINKAMA SVEIKATOS PRIEŽIŪRA: PACIENTŲ NUOMONÉ IR VERTINIMAS
}

\author{
Vinsas Janušonis \\ Klaipédos universitetas, Klaipédos universitetinè ligoniné
}

\begin{abstract}
Anotacija
Straipsnyje nagrinėjamas pacientų sveikatos priežiūros tinkamumas ir kokybė, jų pasitenkinimas sveikatos priežiūra ir lūkesčių išsipildymas didelèje daugiaprofilinèje universitetinèje ligoninèje. Pateikiama individualių, institucinių ir sociodemografinių charakteristikų įtaka pacientų sveikatos priežiūros vertinimui bei jų elgsenai. Tyrimas vykdytas 2004-2015 m. anketinès apklausos metodu. Jis atskleide, kad absoliuti dauguma (93,8 proc.) pacientų sveikatos priežiūra buvo patenkinti ir jos rezultatai atitiko ar viršijo daugumos $(83,8$ proc.) jų lūkesčius. Tyrimo rezultatų pagrindu suformuluotos motyvuotos išvados.

PAGRINDINIAI ŽODŽIAI: Pacientų pasitenkinimas sveikatos priežiūra, sveikatos priežiūros vertinimas, tinkama sveikatos priežiūra, sveikatos priežiūros kokybè.
\end{abstract}

\begin{abstract}
In this article the right healthcare and quality at the big multiprofile university hospital are analyzed in the context of patients' satisfaction and realization their expectations. This paper analyzes impact of individual, institutional, and sociodemographic characteristics on healthcare evaluation and patients behavior. The survey was performed from 2004 to 2015 in Klaipeda University Hospital via questionnaires. The study was showed the majority (93.8\%) of patients was satisfied of health care services and results of the largest part (83.8\%) fallows their expectations. The conclusion are correspond the results of the study.

KEY WORDS: patients' satisfaction and evaluation of healthcare, right healthcare, healthcare quality.
\end{abstract}

\section{Ivadas}

I pacientą orientuota sveikatos priežiūra yra viena pagrindinių sveikatos priežiūros kokybès sudedamųų . Ji apima visą eilę sričių, taip pat paciento sveikatos priežiūros poreikius, jo motyvaciją ir pasirinkimą, informaciją, komunikaciją, vertinimą (Janušonis, 2008; 2016; Lateef, 2011).

Pacientai ir medikai sveikatos priežiūros procese yra tiesiogiai ir nedalomai susiję, todèl pacientų nuomonès apie jų sveikatos priežiūrą išsiaiškinimas ir vertinimas tampa būtinu sveikatos priežiūros atributu.

Sveikatos priežiūros vertinimas susijęs su pacientų sveikatos priežiūros kokybès ir jos sudedamujų supratimu (Bate et al., 2008; Janušonis, 2008; 2016; Murante et al., 2014), tuo, kiek pacientai susipažinę su savo teisėmis (Frampton et al., 2003; LR Pacientų teisių ir žalos sveikatai atlyginimo ịstatymas, 1996; European charter of patients' rights, 2002; Vincent, 2010), jų sveikatos priežiūros lūkesčių 
ir jų išsipildymo santykiu (Mondloch et al., 2001; Bjertnaes et al., 2012; Rowling et al., 2012), pacientų individualiomis charakteristikomis (Perneger, 2004; Janušonis, 2005; 2016; Lehrman et al., 2010).

Pacientų sveikatos priežiūros vertinimui turi reikšmès ne tik individualios, bet ir institucinès bei sociodemografinès charakteristikos. Vertindami sveikatos priežiūrą pacientai remiasi savo patirtimi ir žiniomis, informacija iš aplinkos, medikų informacija, savijauta, gyvenimo kokybès pokyčiais, sveikata priežiūros epizodoprocese ir po jo. Pacientų pasitenkinimo sveikatos priežiūra ir jos vertinimo nereikètų absoliutinti, nes faktiniai (tikrieji, įrodomieji) sveikatos priežiūros rezultatai gali skirtis nuo paciento suvokiamų (Otani et al., 2003; 2012; Gill, White, 2009; Weingart et al., 2011; Siegrist, 2013). Ivvairiose sveikatos priežiūros organizacijose (ligoninèse) priežiūros kokybė, technologijos, medikų profesionalumas, požiūris ì pacientą labai skiriasi, o pacientų vertinimai skiriasi nedaug ir daugiausia jie teigiami (Lloyd, 2004; Ransom et al., 2005). Vis dèlto pacientų nuomonių, jų sveikatos priežiūros vertinimo tyrimas labai svarbus. Jis igalina strateguoti, vykdant pokyčius, organizacijos veiklą, keisti medikų, vadybininkų ir pačios organizacijos elgseną.

Darbo tikslas: ịvertinti pacientų sveikatos priežiūros tinkamumą ir kokybę, pasitenkinimą ja ir jų lūkesčių išsipildymą.

Šio tyrimo svarba ir praktinè verte atskleista aukščiau ir yra neabejotina. Panašių tokio masto tyrimų šalyje nebuvo atlikta.

\section{Tiriamųjų kontingentas ir tyrimo metodika}

Tyrimo populiacija (tirtujų kontingentas) - KUL gydęsi pacientai.

Tyrimo objektas - pacientų nuomoné apie sveikatos priežiūros epizodą KUL (nuo patekimo ị ligoninę iki išrašymo iš jos).

Tyrimo metodai: literatūros analizè, anoniminè anketinè apklausa, statistinè analizè, lyginamoji turinio analizè.

Tyrimui atlikti naudota anoniminè anketa pagal autoriaus (su bendraautoriumi) paruoštą klausimyną. Klausimynas sudarytas atsižvelgiant ị pacientų sveikatos priežiūros kokybės sudedamųjų sampratą (Cleary et al., 1991; Lighter, Fair, 2000; Frampton et al., 2003), LR Paciento teisių ir žalos sveikatai atlyginimo ịstatymo (1996) bei Europos pacientų teisių chartijos (2002) nuostatas, vẻliau, keičiantis teisès aktams, autoriaus papildytas. Klausimyną sudaro 21 klausimas, iš kurių 20 - uždarojo ir 1 - atvirojo tipo. Anketos įteiktos pacientams užpildyti jų išrašymo iš ligoninès dieną. Paciento apklausos jų išrašymo iš ligoninès metu - viena dažniausiai taikomų, didžiausią atsaką duodančių, efektyviausių, mažiau duodančių neteisingai teigiamą rezultatą pacientų sveikatos priežiūros vertinimo metodologijų 
(Sherman et al., 1999; Pettier et al., 2002; Janušonis, 2008; 2016). Jeigu dèl sveikatos būklès ar kitų priežasčių pacientas negalèjo anketos užpildyti, ją užpildydavo kartu buvę paciento artimieji ar slaugytoja pagal paciento atsakymus į klausimus.

Tyrimas vykdytas $2004 \mathrm{~m}$. sausio $1 \mathrm{~d}$. $-2015 \mathrm{~m}$. gruodžio $31 \mathrm{~d}$. ir tęsiamas toliau. Tyrimo duomenys analizuoti ir lyginti 2004-2006 m. ir 2013-2015 m. periodais pagal amžių, lytị, socialinę padètį, patekimo ị ligoninę būdą ir kt. Tirtos 1792221 tinkamai užpildyta anketa. Atsako dažnis tirtuoju laikotarpiu - 77,0 proc. (83,1 proc. $2004-2006$ m. ir 71,0 proc. 2013-2015 m.). Daugumą anketų 83,9 proc. (83,1 proc. $2004-2006 \mathrm{~m}$. ir 84,7 proc. 2013-2015 m.) - užpildė patys pacientai, 11,45 proc. - jų artimieji (11,0 proc. $2004-2006 \mathrm{~m}$. ir 11,9 proc. 2013-2015 m.), 4,65 proc. - slaugytojos (5,9 proc. 2004-2006 m. ir 3,4 proc. 2013-2015 m.).

Daugiau nei du trečdalius $-68,35$ proc. (68,4 proc., $n=57017$ 2004-2006 m. ir 68,3 proc., $n=655042013-2015 \mathrm{~m}$.) - tirtų pacientų sudare moterys, apie vieną trečdali - 31,65 proc. (31,6 proc., $n=261362004-2006 \mathrm{~m}$. ir 31,7 proc., $n=303852014-2016 \mathrm{~m}$.) vyrai.

Pagal amžių pacientai suskirstyti ị aštuonias grupes kas dešimt metų (iki $20 \mathrm{~m}$. - vyresni kaip $80 \mathrm{~m}$. intervalu). Daugumą sudare 20-29 m. $-19,15$ proc., $n=34$ 047 (20,7 proc., $n=172462004-2006 \mathrm{~m}$. ir 17,5 proc., $n=168012013-2015$ m.) ir 70-79 m. $-15,35$ proc., $n=27590$ (14,8 proc., $n=123122004-2006 \mathrm{~m}$. ir 15,9 proc., $\mathrm{n}=152782013-2015 \mathrm{~m}$.) pacientai.

Mažiausiai buvo pacientų iki $20 \mathrm{~m}$. $-8,3$ proc., $n=14879(8,5$ proc., $n=7085$ 2004-2006 m. ir 8,1 proc., $n=77942013-2015 \mathrm{~m}$.) ir vyresniu kaip $80 \mathrm{~m}$. 6,45 proc., $n=11799$ (4,7 proc., $n=39142004-2006 \mathrm{~m}$. ir 8,2 proc., $n=7885$ 2013-2015 m.).

Dirbančiujų buvo 42,75 proc., $n=76647$ (42,6 proc., $n=355302004$ $2006 \mathrm{~m}$. ir 42,9 proc., $n=411172013-2015 \mathrm{~m}$.), pensininkų ir neigaliujų 36,3 proc., $n=64831$ (37,8 proc., $n=315052004-2006 \mathrm{~m}$. ir 34,8 proc., $n=333262013-2015 \mathrm{~m}$.), studentu ir moksleiviu - 6,35 proc., $n=11566$ (5,0 proc., $n=41962004-2006 \mathrm{~m}$. ir 7,7 proc., $n=73702013-2015 \mathrm{~m}$., bedarbiu 2,7 proc., $n=20876$ (13,5 proc., $n=112562004-2006 \mathrm{~m}$. ir 10,0 proc., $n=9620$ 2013-2015 m.).

Likusieji savo darbinio statuso nenurodè ar nurodè netiksliai (kelis variantus). Dirbančių moterų buvo tris kartus, bedarbių moterų - du kartus, neigalių moterų ir pensininkių - du kartus, studentų ir moksleivių - du kartus daugiau nei vyrų.

Analizuojamais laikotarpiais esminio, statistiškai patikimo pokyčio pagal pacientų amžiaus grupes, lytị bei socialinę padètị nenustatyta.

Respondentų apimtys reprezentuoja šalies didelių, daugiaprofilinių, išplètotos infrastruktūros ligoninių stacionarų pacientus. 
Statistinè duomenu analizè atlikta SPSS 17,0.1 for Windows ir Microsoft Office Exel 2003 programomis. Statistinių duomenų reikšmingumas tikrintas taikant Spearmen ir Pearson $x^{2}$ kriterijus. Duomenų skirtumas laikytas statistiškai reikšmingu, kai $p<0,05$ (statistinis pasikliautinumo lygmuo - 95 proc.).

\section{Rezultatai ir jų aptarimas}

Dauguma tirtu pacientu - 35,8 proc. atvyko bendrosios praktikos gydytojo (BPG) siuntimu (34,9 proc. 2004-2006 m. ir 26,7 proc. 2013-2015 m.). Statistiškai reikšmingai sumažèjo atvykusiujų i ligoninę BPG siutimu skaičius lyginamaisiais periodais.

Kiti pasiskirste beveik po lygiai. Su gydytojo konsultanto siuntimu atvyko 28,5 proc. (21,2 proc. $2004-2006 \mathrm{~m}$. ir 24,9 proc. $2013-2015 \mathrm{~m}$.), su greitosios medicinos pagalbos (GMP) siuntimu - 20,3 proc. (22,2 proc. $2004-2006 \mathrm{~m}$. ir 18,4 proc. 2013-2015 m.), atvyko patys - 20,9 proc. (20,6 proc. $2004-2006 \mathrm{~m}$. ir 21,2 proc. 2013-2015 m.). Likusieji pacientai patekimo būdo ị ligoninę nenurodẻ ar nurodè netiksliai.

Pusė dirbančiųu (50,15 proc.) hospitalizuoti skubos tvarka (56,5 proc. 20042006 m. ir 43,8 proc. 2013-2015 m.), bedarbiu skubos tvarka hospitalizuota daugiau nei pusė - 55,2 proc. (60,2 proc. $2004-2006 \mathrm{~m}$. ir 50,2 proc. 2013 2015 m.). Studentai ir moksleiviai skubos tvarka hospitalizuoti 57,25 proc. atveju (49,2 proc. 2004-2006 m. ir 65,3 proc. 2013-2015 m.). Hospitalizuojamų skubos tvarka studentu ir moksleivių skaičius per 10 metų statistiškai reikšmingai padidejo. Pensininkų ir neigaliųu skubos tvarka hospitalizuota apie trečdalis 36,1 proc. (35,3 proc. $2004-2006$ m. ir 36,8 proc. 2013-2015 m.). Iš viso skubos tvarka hospitalizuota 44,8 proc. tirtų pacientų (48 proc. 2004-2006 m. ir 41,6 proc. 2013-2015 m.). Vyrų ir moterų, hospitalizuotų skubos tvarka, skaičius statistiškai patikimai nesiskyrè. Daugiau nei du trečdaliai atvykusių ị ligoninę pacientu buvo apžiūreti tuoj pat (50,7 proc.) arba per pusę valandos (29 proc.) (53,3 proc. ir 29 proc. $2004-2006 \mathrm{~m}$. bei 48,1 proc. ir 29 proc. 2013-2015 m.). Likusieji, daugiausia planine tvarka atvykę pacientai, apžiūrèti vẻliau. Daugiau nei po valandos apžiūrèti 2,9 proc. pacientų.

Nedidelè dalis pacientų nurodè, kad gydytojo prièmimo skyriuje nebuvo apžiūrèti. Nustatyta, kad tai tie pacientai, kurie pateko tiesiai ị reanimacijos skyrių. Dauguma pacientų (78,7 proc.) į skyrių pateko per $30 \mathrm{~min}$., 11,85 proc. - per valandą po gydytojo apžiūros prièmimo skyriuje (80,6 proc. ir 12,6 proc. $2004-2006 \mathrm{~m}$. ir 76,7 proc. ir 11,1 proc. 2013-2015 m.). Esminio skirtumo analizuojant pacientu apžiūros prièmimo skyriuje ir patekimo ị skyrių laikus pagal amžiaus grupes, lytị ir socialinę padètį nenustatyta. 
KUL nustatyta kokybės procedūra, pagal kurią skubos tvarka pacientai hospitalizuojami ị skyrių per 30 min., planine tvarka - per vieną valandą. Vèliau nei per valandą stacionarizuoti pacientai dèl užtrukusių diagnostinių tyrimų, nedidelè dalis - dèl vienu metu atvykusių kelių ligonių. Dauguma pacientu (88,0 proc.) hospitalizuotų planine tvarka ir 91 proc. - skubos tvarka apžiūrimi skyriuje gydančio ar budinčio gydytojo per $30 \mathrm{~min}$. Tik 4,05 proc., iš kurių absoliuti dauguma hospitalizuotų planine tvarka pacientų, apžiūrimi po valandos. Esminio skirtumo analizuojamais laikotarpiais ir pagal amžiaus grupes, lytị bei socialinę padètį nenustatyta.

Beveik penktadalio pacientų (18,5 proc.) tyrimai pradedami jau prièmimo (skubios pagalbos) skyriuje (19 proc. 2004-2006 m. ir 18 proc. 2013-2015 m.). Daugelio pacientu (76,45 proc.) gydymas pradedamas per $30 \mathrm{~min}$. (80,5 proc. 2004-2006 m. ir 72,4 proc. 2013-2015 m.), 8,6 proc. - vèliau nei po valandos (8,9 proc. $2004-2006$ m. ir 7,2 proc. $2013-2015$ m.). Tai normalūs intensyviai dirbančių daugiaprofilinių ligoninių rodikliai.

Ketvirtadaliui (24 proc.) pacientų kitų specialybių gydytojų konsultacijos nereikejjo. Tačiau analizuojamais laikotarpiais konsultuotų pacientų skaičius statistiškai reikšmingai augo (2004-2006 m. papildomų konsultacijų nereikejjo 31,1 proc. pacientų, 2013-2015 m. - 16,8 proc.). Daugiau nei pusę pacientų (52,7 proc.) konsultavo 1-2 specialistai (49,8 proc. 2004-2006 m. ir 55,6 proc. 2013-2015 m.). Likusius konsultavo daugiau nei du specialistai. Pagal darbinị statusą daugiausia gydytojai specialistai konsultavo dirbančiuosius (78,1 proc.) ir neiggaliuosius bei pensininkus (74,1 proc.). Esminių skirtumų pagal amžiaus grupes ir lytị nestebèta. Gydytojų konsultacijų skaičius teigiamai veikia pacientų pasitenkinimą sveikatos priežiūra ir jos vertinimą (Pettier et al., 2002; Janušonis, 2008).

Gydytojų teikiamą informaciją, kaip nepakankamą, vertino 0,4 proc. pacientų (0,5 proc. 2004-2006 m. ir 0,3 proc. 2013-2015 m.), slaugytoju - 0,2 proc. (analizuojamais laikotarpiais nesiskyrè). Likę pacientai medikų teikiamą informaciją vertino kaip pakankamą. Pacientų informuotumas apie teikiamą sveikatos priežiūrą, jos galimybes, alternatyvas, rezultatus daro didelę ịtaką jiems priimant sprendimus ir ją vertinant (Janušonis, 2005; 2016; Studer, 2003). Absoliuti dauguma pacientu ( 94,3 proc.) nurodè, kad priimant sprendimus dèl jų sveikatos priežiūros (tyrimų, gydymo ir kt.) jie dalyvavo, su jais tartasi (96,6 proc. 2004-2006 m. ir 91,8 proc. 2013-2015 m.). 1,05 proc. pacientų priimant sprendimus dèl jų sveikatos priežiūros nedalyvavo (1,3 proc. $2004-2006 \mathrm{~m}$. ir 0,8 proc. 2013-2005 m.), nes to nenorëjo patys pacientai - pasitikejjo gydytojais. Paciento dalyvavimas priimant su jo sveikatos priežiūra susijusius sprendimus yra šiuolaikinio mediko ir paciento bendravimo pagrindas bei tam tikras iššūkis medikams (Smits et al., 2010; Janušonis, 2016).

Absoliuti dauguma pacientu galëjo, kada to norejo, pasikalbèti su gydančiu gydytoju apie savo sveikatą ir sveikatos priežiūrą. To padaryti, kada panorèję, ne- 
galèjo 0,55 proc. pacientu ( 0,6 proc. $2004-2006 \mathrm{~m}$. ir 0,5 proc. $2013-2015 \mathrm{~m}$.). Atkreiptinas dèmesys, kad 2,75 proc. pacientu nereikèjo papildomai savo iniciatyva kalbètis su gydytoju, t. y. jie gaudavo visą informaciją laiku iš medicinos darbuotojų (analizuojamais laikotarpiais pacientų dalis nesiskyrè).

Dalis pacientų - 28,9 proc. nurode gydymosi periodu jautę skausmą (27,1 proc. 2004-2006 m. ir 30,7 proc. 2013-2015 m.), 88,4 proc. jų buvo taikomi skausmą malšinantys vaistai. Nedidelè dalis pacientų ( 3,4 proc.) nurodè, kad jiems jaučiant skausmą, skausmą malšinantys vaistai netaikyti (5,1 proc. 2004-2006 m. ir 1,7 proc. 2013-2015 m.). Pažymètina, kad absoliuti dauguma šių pacientų - gimdyvès. Teigiama yra tai, kad pastaruoju metu skausmą malšinantys vaistai gimdymo skausmų atveju dažniau taikomi.

Dalis pacientu (26,35 proc.) nurodè, kad besigydydami ligoninèje papildomai ịsigijo (ar naudojo savo) medikamentų (24,2 proc. 2004-2006 m. ir 28,5 proc. 2013$2015 \mathrm{~m}$.). Tai numato galiojantys teisès aktai ir daroma paciento noru ir pasirinkimu, įsigyjant brangesnius ir (ar), jų nuomone, efektyvesnius vaistus ar priemones.

Absoliuti dauguma pacientų slaugos paslaugomis buvo patenkinti ir jas vertino kaip pakankamas. Kad slaugos paslaugos buvo nepakankamos nurode 1,4 proc. pacientų (analizuojamais laikotarpiais ši dalis nesiskyrè).

Daugiau nei trys ketvirtadaliai (83,2 proc.) pacientų leido teikti informaciją apie jų buvimą ligoninèje ir sveikatos būklę (94,9 proc. 2004-2006 m. ir 77,8 proc. 2013-2015 m.), 2,7 proc. tokios informacijos teikti neleido (1,4 proc. 2004-2006 m. ir 3,7 proc. $2013-2015$ m.) (1 lentelè).

1 lentelè. Pacientų suteiktas leidimas teikti informaciją apie jų buvimą ligoninèje ir sveikatos būklę

\begin{tabular}{|l|l|l|l|l|l|l|}
\hline \multicolumn{1}{|c|}{ Laikotarpis } & \multicolumn{2}{c|}{$2004-2006 \mathrm{~m}}$. & \multicolumn{2}{c|}{$2013-2015 \mathrm{~m}}$. & \multicolumn{2}{c|}{ Iš viso } \\
\hline \multicolumn{1}{|c|}{ Informacijos teikimas } & \multicolumn{1}{c|}{$n$} & proc. & \multicolumn{1}{c|}{$n$} & proc. & \multicolumn{1}{c|}{$n$} & proc. \\
\hline Leido teikti informaciją & 75059 & 94,9 & 73984 & 77,8 & 149043 & 83,2 \\
\hline Neleido teikti informacijos & 1158 & 1,4 & 3592 & 3,7 & 4750 & 2,7 \\
\hline Darbuotojai apie tai neklause & 2197 & 2,6 & 9678 & 10,1 & 11875 & 6,6 \\
\hline Nenurodė & 920 & 1,1 & 8635 & 8,4 & 9555 & 7,5 \\
\hline Iš viso & 83333 & 100 & 95889 & 100 & 179222 & 100 \\
\hline
\end{tabular}

Pažymètina, kad pastaruoju metu pacientai linkę mažiau atskleisti informacijos kitiems asmenims, nei prieš dešimtmetị. Moterys linkusios mažiau atskleisti informacijos nei vyrai: neleido teikti informacijos 4,1 proc. moteru ir 3,1 proc. vyru. Mažiau linkę atskleisti informacijos dirbantieji (4,3 proc.) ir 30-59 metų asmenys (4,8 proc.). 95,0 proc. pacientų, neleidusių teikti informacijos apie save, nurodè, kad šis jų pageidavimas įvykdytas - privatumas užtikrintas (91,9 proc. 2004-2006 m. ir 98,1 proc. 2013-2015 m.). Vis dèlto nedidelei daliai pacientu privatumas, 
jų nuomone, nebuvo užtikrintas. Tai, mūsų nuomone, ịvyko dèl didelès pacientų medicininès dokumentacijos sklaidos.

Analizuojant pacientų pasitenkinimą teikta sveikatos priežiūra, daugelis nurodè, kad buvo visiškai (78 proc.) ar iš dalies ( 15,8 proc.) patenkinti (2 lentelè).

2 lentelè. Pacientų pasitenkinimas sveikatos priežiūra ligoninèje

\begin{tabular}{|l|c|c|c|c|c|c|}
\hline \multicolumn{1}{|c|}{ Laikotarpis } & \multicolumn{2}{c|}{$2004-2006 \mathrm{~m}}$. & $2013-2015 \mathrm{~m}$. & \multicolumn{2}{c|}{ Iš viso } \\
\hline Pasitenkinimas sveikatos priežiūra & $n$ & proc. & $n$ & proc. & $n$ & proc. \\
\hline Visiškai patenkinti & 63804 & 76,6 & 75926 & 79,2 & 139730 & 78,0 \\
\hline Patenkinti & 18449 & 22,1 & 9806 & 10,2 & 28255 & 15,8 \\
\hline Nepatenkinti & 158 & 0,2 & 205 & 0,2 & 363 & 0,2 \\
\hline Nenurodė & 922 & 1,1 & 9952 & 10,4 & 10874 & 6,0 \\
\hline Iš viso & 83333 & 100 & 95889 & 100 & 179222 & 100 \\
\hline
\end{tabular}

Nepatenkintų sveikatos priežiūros paslaugomis pacientų dalis, nepaisant amžiaus grupès, lyties ar socialinès padèties bei analizuojamo laikotarpio, išliko ta pati nedidelè ( 0,2 proc.). Atliekant išsamesnę anketų analizę, nustatyta tiesioginé nepatenkintujų sveikatos priežiūros paslaugomis koreliacija su sveikatos priežiūros rezultatais (išeitimis), kurie, deja, ne visada priklauso nuo medikų.

Analizuojant pacientų lūkesčius ir sveikatos priežiūros rezultatus (pačiu pacientų vertinimu) 41,9 proc. nurodè, kad rezultatai yra geresni nei tikejjosi ir viršijo jų lūkesčius, tiek pat pacientų (41,9 proc.) nurodè, kad rezultatai tokie, kokių tikèjosi, t. y. atitiko jų lūkesčius.

Kas dešimtas pacientas negalëjo tiksliai pasakyti, o kas dvidešimtas - nenurodè. Tik nedidelè pacientų dalis nurodè, kad jų sveikatos priežiūros rezultatai blogesni nei tikèjosi (3 lentelè).

3 lentele. Pacientų nuomonè apie sveikatos priežiūros ligoninèje rezultatus

\begin{tabular}{|l|c|c|c|c|c|c|}
\hline \multicolumn{1}{|c|}{ Laikotarpis } & \multicolumn{2}{c|}{$2004-2006 \mathrm{~m}}$. & $2013-2015 \mathrm{~m}$. & \multicolumn{2}{c|}{ Iš viso } \\
\hline Rezultatai & $n$ & proc. & $n$ & proc. & $n$ & proc. \\
\hline Geresni, nei tikèjosi & 36323 & 43,6 & 38785 & 40,4 & 75108 & 41,9 \\
\hline Tokie, kokių tikėjosi & 35782 & 42,9 & 39225 & 40,9 & 75007 & 41,9 \\
\hline Blogesni nei tikèjosi & 491 & 0,6 & 664 & 0,7 & 1155 & 0,6 \\
\hline Negali tiksliai pasakyti & 9815 & 11,8 & 9456 & 9,9 & 19271 & 10,8 \\
\hline Nenurodė & 922 & 1,1 & 7759 & 8,1 & 8681 & 4,8 \\
\hline Iš viso & 83333 & 100 & 95889 & 100 & 179222 & 100 \\
\hline
\end{tabular}


Sveikatos priežiūros rezultatų lūkesčių išsipildymas nepriklausẻ nuo lyties ar socialinès padèties, tačiau rezultatus vertino kaip blogesnius, nei tikejjosi, daugiau 40-69 metų amžiaus grupès pacientai ( 0,9 proc.). Tai atitinka literatūros duomenis, kur nurodoma, kad toks vertinimas būdingesnis vidutinio ir vyresnio amžiaus žmonėms (Rove, Calnan, 2006; Attiech et al., 2013). Labai maža dalis pacientu buvo nevisiškai patenkinti gydytojų ( 0,1 proc.) ir slaugytojų $(0,9$ proc.) darbu, 0,1 proc. pacientų nepakako darbuotojų pagarbos. 2,2 proc. pacientų nepatiko maistas, 1,5 proc. patalpos atrodè nepakankamai jaukios ir švarios. Analizuojant šių pacientų kontingentą, dauguma jų buvo sergantys sunkiomis (onkologinemis ir kt.) ligomis, slaugomi pacientai, jų anketas pildè artimieji.

Absoliuti dauguma tirtų pacientų rinktųsi ligoninę, jeigu reikètų ir kitą kartą bei rekomenduotų ją savo artimiesiems ir pažįstamiems. Nesirinktų ligoninės pakartotinai 0,4 proc. ir nerekomenduotu jos kitiems 0,4 proc. pacientų. Pacientų kartotinis tos pačios ligoninès pasirinkimas ir rekomendavimas jos kitiems, jų sveikatos priežiūros kokybès vertinimas bei pasitenkinimas ja yra tarpusavyje susiję (Burgers et al., 2010; Otani et al., 2012).

Atkreiptinas dèmesys, kad pacientai retai neigiamai vertina tam tikrus sveikatos priežiūros aspektus: neigiami atsakymai daugiausia yra visais sveikatos priežiūros aspektais. Tai atitinka literatūros duomenis: pacientai, skirtingai nei medikai, sveikatos priežiūros procesą vertina visą, nors nepakankama buvo tik tam tikra jo dalis. Pacientų sveikatos priežiūros vertinimas labiau susijęs su jų lūkesčių išsipildymu, nei su konkrečiais rezultatais. Bent vienas neigiamas momentas gali formuoti neigiamą paciento požiūrị ị teikiamą sveikatos priežiūrą ir gali nulemti viso sveikatos priežiūros epizodo vertinimą (Janušonis, 2005; 2008; 2016; Vincent, 2010).

Vertinant sveikatos priežiūrą reprezentacinèse respondentų amžiaus grupèse pagal hospitalizacijos pobūdị (skubi ar planinè), lytị, socialinę padètị, nustatyta, kad pagal esminius kvalifikacinius požymius: gydytojo apžiūrą per 30 min. (a), daugiau nei vieno specialisto konsultaciją (b), papildomai ịsigytus ar vartotus savo vaistus arba priemones (c), pasitenkinimą suteiktomis paslaugomis (d), sveikatos priežiūros rezultatus (e), pakartotinị ligoninès rinkimąsi, prireikus (f) ir ligoninès rekomendavimą savo artimiesiems bei pažistamiems (g) esminių sveikatos priežiūros nelygybès, prieinamumo ir kokybès skirtumų nestebèta.

Analizuojant respondentų atsakymus ị anketos klausimus pagal amžiaus grupes, lytị, socialinę padètị ir laikotarpius, rezultatai panašūs arba skirtumai nedideli. Tai rodo, kad absoliuti dauguma anketų buvo užpildytos laisvai ir sąžiningai, atsakymai atskleidžia realią pacientų nuomonę.

Sveikatos priežiūros organizacijų kokybės siekio, jų vadybos orientacija ị pagrindines pacientų pasitenkinimo sveikatos priežiūra ir jų vertinimo sudedamąsias - prieinamumą, medikų ir kito personalo elgseną, profesionalumą ir bendravimą 
su pacientais, nemedicinines paslaugas (maistas, patogumai, švara), šiuolaikines technologijas - yra viena svarbiausių tinkamos sveikatos priežiūros sąlygų (Bodenheimer et al., 2002; Otani et al., 2012; Lis et al., 2015; Janušonis, 2016). Tai patvirtino atliktas tyrimas.

Sveikatos priežiūros rezultatus pacientai vertino šiek tiek atsargiau: nors kaip blogesnius nei tikejjosi įvertino labai nedidelis pacientų skaičius, tačiau kas dešimtas negalejjo tiksliai atsakyti apie juos. Tai patvirtina, kad pacientų sveikatos priežiūros proceso pradžios ir rezultatų lūkesčiai netapatūs. Pacientų lūkesčiai dèl sveikatos priežiūros ir jos rezultatų yra aukštesni, nei realios sveikatos priežiūros galimybès.

Šio tyrimo rezultatai panašūs ị kitų šalių mokslininkų rezultatus (Ransom et al., 2005; Bjertnaes et al., 2012; Rowling et al., 2012; Janušonis, 2016).

Tyrimas patvirtino, kad pacientų nuomonès apie sveikatos priežiūros tinkamumą tyrimas jų išrašymo iš ligoninės metu yra subtilus įrankis ir efektyvus metodas sveikatos priežiūros kokybei gerinti.

\section{Išvados}

1. KUL analizuojamais 2004-2006 m. ir 2013-2015 m. laikotarpiais teikta sveikatos priežiūra absoliučiai daugumai pacientų buvo tinkama.

2. Absoliuti dauguma pacientų, vertindami sveikatos priežiūros rezultatus, nurode, kad jie viršijo ar atitiko jų lūkesčius ir jie tokia sveikatos priežiūra yra patenkinti.

3. Absoliuti dauguma pacientų prireikus rinktųsi ligoninę pakartotinai ir ją rekomenduotų savo artimiesiems bei pažįstamiems.

4. Sveikatos priežiūros diferenciacijos (nelygybès) lyties, amžiaus, socialinès padèties ar užimtumo aspektais nestebèta.

Gauta 20160906

Pasirašyta spaudai 20161203

\section{Literatūra}

Attiech, R., Gagnon, M. P., Estabrooks, C. E. et al. (2013). Organizational readiness for knowledge translation in chronic care: a review of theoretical components. Implementation Science, Vol. 8, p. 138-148.

Bate, P., Mendel, P., Robert, G. (2008). Organizing for quality. Abington, UK: Radcliffe Publishing.

Bjertnaes, O. H., Sjetne, I. S., Iversen, H. H. (2012). Overall patient satisfaction with hospitals: effects of patient - reported experiences and fulfillment of expectations. British Medical Journal Quality and Safety, Vol. 21, p. 39-416.

Bodenheimer, T., Lorig, K., Holman, H., Grumbach, K. (2012). Patient self-management of chronic disease in primary care. The Journal of the American Medical Association, Vol. 288, p. 2469-2475.

Burgers, J. S., Voerman, G. E., Grol, R. et al. (2010). Quality and coordination of care for patients with multiple conditions: results from on international survey of patient experience. Evaluation of Health Professional, Vol. 33, p. 343-364. 


\section{Mari Kivistö}

Cleary, P. D., Edgman-Levitan, S., Roberts, M. et al. (1991). Patients evaluate their hospital care. A national survey. Health Affairs (Millwood), Vol. 10, p. 254-267.

European charter of patients' rights. (2002). Brussels.

Frampton, S. M., Gilpin, L., Charmel, P. (2003). Putting patients first. San-Francisco: Jossey-Bass.

Gill, L. White, L. (2009). A critical review of patients satisfaction. Leadership in Health Services, Vol. 22, p. 8-19.

Janušonis, V. (2005). Rizikos valdymas sveikatos priežiūros organizacijose. Klaipėda: S. Jokužio leidyklaspaustuvè.

Janušonis, V. (2008). Sveikata ir valdoma sveikatos priežiūra. Klaipėda: S. Jokužio leidykla-spaustuvė.

Janušonis, V. (2016). Rizikos valdymas sveikatos priežiūros organizacijose: sisteminè teoriné-praktiné apžvalga. Klaipėda: S. Jokužio leidykla-spaustuvè.

Lateef, F. (2011). Patient expectations and the paradigm shift of care in emergency medicine. Journal of Emergencies, Trauma, and Shock, Vol. 4, p. 163-167.

Lehrman, W. G., Elliott, M. N., Goldstein, E. et al. (2010). Characteristics of hospitals demonstrating superior performance in patients experience and clinical process measures of care. Medical Care Research and Review, Vol. 67, p. 38-55.

Lighter, D. E., Fair, D. C. (2000). Principles and methods of quality management in health care. Gaidhersburg, Maryland: Aspen Publishers, Inc.

Lis, C. G., Patel, K., Gupta, D. (2015). The relationship between patient satisfaction with service quality and survival in non-small cell lung cancer - is self-related health a patient confounder? Online, doi:10.1371/ journal.pone.0134617.

Lloyd, R. (2004). Quality Health Care: a Guide to Developing and Using Indicators. London: Jones and Bartlett Publishers Int.

LR pacientų teisių ir žalos sveikatai atlyginimo įstatymas. (1996). Spalio 3 d., Nr. 1-1562.

Mondloch, M. V., Cole, D. C., Frank, J. W. (2001). Does how you do depend on how think you'll do? A systematic review of the evidence for a relation between patients' recovery expectations and health outcomes. Canadian Medical Association Journal, Vol. 165, p. 391-415.

Murante, A. M., Seghieri, C., Brown, A., Nuti, S. (2014). How do hospitalization experience and institutional characteristics influence impaction satisfaction? A multilevel approach. International Journal of Health Planning and Management, Vol. 14, p. 247-260.

Otani, K., Harris, L. E., Tierney, W. M. (2003). Paradigm shift in patient satisfaction assessment. Medical Care Research Review, Vol. 60, p. 347-365.

Otani, K., Kim, B. J., Waterman, B. et al. (2012). Patient satisfaction and organizational impact: a hierarchical linear modeling approach. Health Marketing Quarterly, Vol. 29, p. 256-269.

Perneger, R. V. (2004). Adjustment for patient characteristics in satisfaction surveys. International Journal for Quality in Health Care, Vol. 16, p. 433-435.

Pettier, M. D., Ford, R. C., Heaton, C. P. (2002). Achieving Service Excellence: Strategies for Health Care. Chicago, Illinois: Health Administration Press.

Ransom, S. B., Joshi, M. S., Nash, D. S. (2005). The Healthcare Quality Book: Vision, Strategy, and Tools. Washington D.C.: AUPHA Press.

Rove, R., Calnan, M. (2008). Trust relations in health care - the new agenda. The European Journal of Public. Health, Vol. 16, p. 4-6.

Rowling, A., Rowe, G., Lambert, N. et al. (2012). The measurement of patients' expectations for health care: a review and psychometric testing of a measure of patients expectations. Health Technology Assessment, Vol. 16, p. 1-50s.

Sherman, S. G., Sherman, V. C. (1999). Total Customer Satisfaction: A Comprehensive Approach for Health Care Providers. San-Francisco: Jossey-Bass.

Siegrist, R. B. (2013). Patient satisfaction: history, myths, and misperceptions. American Medical Asssociation, Journal of Ethics, Vol. 115, p. 982-987.

Smith, M., Zegers, M., Groenewegen, P. P. et al. (2010). Exploring the causes of adverse events in hospital and potential prevention strategies. Quality and Safety in Health Care, Vol. 19, p. 5-15.

Studer, Q. (2003). How health care vins with consumers who want more. Front Health Service Management, Vol. 19 , p. 3-16.

Vincent, C. (2010). Patient safety. $2^{\text {nd }}$ ed. Chichester: Viley-Blackwell.

Weingart, S. N., Pagovich, O., Sands, D. Z. et al. (2006). Patient - reported service quality on a medicine unit. International Journal for Quality in Health Care, Vol. 18, p. 95-101. 


\section{RIGHT HEALTHCARE AND QUALITY: PATIENTS' OPINION AND EVALUATION}

\section{Vinsas Janušonis}

\section{Summary}

Background. Patient centered healthcare - the main component of healthcare quality. The patients opinion and evaluation of healthcare is coming obligatory attribute of health care organizations.

The patients' assessment empowers to plan the strategy, and changes of organization, to exchange behavior and activity of staff and organization.

The aim of the study - to estimate the adequacy and quality of health care, patients' satisfaction and fruition of expectations.

Material and methods. From January 2004 to December 2006 and from January 2013 to December 2015 a survey was performed in Klaipeda University Hospital. The study included 179222 patients who were undergoing treatment in the hospital. Information was collected via questionnaires (response rate was $77 \%$ ).

Results and discussion. The majority inquired patients were fully (78\%) or partly $(15.8 \%)$ satisfy of health care services (not satisfied $0.2 \%$ ). According to the findings of study, $41.9 \%$ of patients thought results of health care are better they were expecting and $41.9 \%$ of patients thought results are as fallows they will expected.

Only $0.6 \%$ of patients thought their expectations not to come true.

The total majority of patients will choose the same hospital in the future and will recommend it for the friends and acquaintances (only $0.4 \%$ and $0.4 \%$ accordingly will not doing that).

Conclusion. Nearly all inquired patients stated health care was right and qualified.

The majority of patients assess the results of healthcare as exceed or fallows their expectations and they are satisfied with such healthcare.

The total majority of patients will choose the same hospital in the future and will recommend it for the friends and acquaintances.

There were no essential differences in availability and equality of health care service between inqueried patients according to gender, age, social group and employment. 
